\title{
Distribution and Prevalence of Fusarium Crown Rot and Common Root Rot Pathogens of Wheat in Montana
}

Ernesto A. Moya-Elizondo, Instituto de Producción y Sanidad Vegetal, Facultad de Ciencias Agrarias, Universidad Austral de Chile, Valdivia, Chile; Lisa J. Rew, Department of Land Resources and Environmental Sciences, and Barry J. Jacobsen, Andrew C. Hogg, and Alan T. Dyer, Department of Plant Sciences and Plant Pathology, Montana State University, Bozeman 59717

\begin{abstract}
Moya-Elizondo, E. A., Rew, L. J., Jacobsen, B. J., Hogg, A. C., and Dyer, A. T. 2011. Distribution and prevalence of Fusarium crown rot and common root rot pathogens of wheat in Montana. Plant Dis. 95:1099-1108.

Distribution of Fusarium crown rot (FCR) and common root rot (CRR) pathogens associated with wheat (Triticum aestivum) in 91 fields in Montana were determined during the 2008 and 2009 crop seasons using real-time quantitative polymerase chain reaction (qPCR) and conventional isolation methods. Correlations $(P<0.001)$ were found between detection methods for both diseases. FCR was detected in $57 \%$ of the fields and CRR was detected in $93 \%$ of the fields surveyed. Percent incidence based on isolation from individual tillers was Bipolaris sorokiniana (15\%), F. culmorum (13\%), and F. pseudograminea-

and were not detected in any fields from the Gb5 soil types of Judith Basin and Fergus counties. The spatial distributions of FCR and CRR were affected by elevation, soil type, and temperature. High FCR populations were associated with spring wheat crops rather than winter wheat based on qPCR $(P<0.001)$. FCR and CRR could produce yield losses in a range of 3 to $35 \%$. This study is the first time that qPCR was used to survey these two pathogen groups, and the merits and weakness of qPCR relative to traditional isolation methods are discussed.
\end{abstract} rum $(8 \%)$. FCR populations were highly variable across the regions
Fusarium crown rot (FCR) and common root rot (CRR) are important diseases of wheat and barley, causing yield losses, stand reductions and rotting of root, crown, subcrown, and lower stem tissues $(18,19,21,24,44)$. FCR is generally accepted as a disease complex dominated by different pathogens in different areas or even by different pathogens during successive growing seasons in individual fields (44). The FCR complex most commonly involves Fusarium culmorum (W.G. Sm.) Sacc., F. pseudograminearum (O’Donnell \& T. Aoki; group I) (= Gibberella coronicola), and $F$. graminearum Schwabe (group II) (= G. zeae (Schwein.) Petch) $(43,55)$. In some regions, F. avenaceum (Fr.) Sacc., F. acuminatum Ellis \& Everh., F. equiseti (Corda) Sacc., and Microdochium nivale (Fr.) Samuels \& I.C. Hallett (=F. nivale (Fr.) Sorauer) have also been associated with FCR (44). In contrast to FCR, CRR is caused solely by Bipolaris sorokiniana (Sacc.) Shoemaker (= Cochliobolus sativus (S. Ito \& Kuribayashi) Drechsler ex Dastur). Because FCR and CRR are perennial and widespread problems in wheat and barley production, several surveys have been conducted to determine the pathogens involved, estimate yield losses, and examine environmental factors associated with these diseases. Surveys have been carried out in the Pacific Northwest $(12,55)$, Canadian Prairies $(18,19,21,24,26)$, Texas Panhandle (57), southeastern Idaho (58), upper coastal plain area of Mississippi (25), Colorado and Wyoming (28), Australia $(4,17,50,66,67)$, United Kingdom (45), Turkey (63), northwestern Iran (46), and Brazil (14). Unfortunately, none of these surveys have included the major productions areas of Montana where heavy root and crown rot losses have recently been reported (29).

Although wheat production in Montana is widely dispersed, the north-central and central regions of the state, known as "the Golden Triangle", represent approximately $43.5 \%$ of the state's 2.19 million ha of annual wheat production (http://www.nass.

Corresponding author: A. Dyer, E-mail: adyer@montana.edu

Accepted for publication 2 April 2011.

doi:10.1094/PDIS-11-10-0795

(C) 2011 The American Phytopathological Society usda.gov). Within this region, adoption of no-till farming practices has become popular because they conserve soil moisture, fuel, and labor inputs, plus reduce soil erosion $(15,30)$. The adoption of notill wheat-cropping systems has also been linked to increased severity of FCR $(9,41,52)$ and CRR (67). In Montana's wheat agroecosystem, incorporation of no-till and conservation tillage system practices may also be associated with a possible change in FCR pathogen species from $F$. culmorum to F. pseudograminearum (15). Other production practices in addition to tillage that have been linked to increased FCR and CRR severity include short or no-crop rotations and glyphosate herbicide treatments used in chemical fallow or pre-plant weed control $(18-20,22,24)$. Information regarding disease and pathogen incidence, yield losses, and the associated production practices is needed in order to better target control practices in the Golden Triangle. Also, documentation of cropping practices is important, considering the impact of cropping practices on dryland root rot diseases and the widespread perception that these diseases are becoming more important.

To date, FCR and CRR surveys have been primarily conducted through the isolation and culturing of fungal pathogens from infected tissues or through the assessment of visual symptoms characteristic for the respective diseases. The isolation methods typically used for these surveys are labor intensive and are often confounded by factors such as competition and antagonism from other organisms within the tissues, the expertise of the individuals isolating and identifying species, and the selectivity and sensitivity of the media assays (30). On the other hand, visual assessment of the diseases is labor intensive, less pathogen specific, and subject to the vagaries of the individuals involved $(29,56)$. With the introduction of quantitative real-time polymerase chain reaction (qPCR assays), these problems may be solved because qPCR has the potential to make disease assessments quickly and accurately (48). The value of qPCR for conducting disease surveys has already been demonstrated for a number of plant disease systems $(31,32,35,65)$.

Because of the need to understand the disease dynamics in Montana and the advent of modern molecular methods, this study was conducted to assess the distribution and pathogen populations associated with FCR and CRR across commercial wheat fields in the Golden Triangle of Montana. To accomplish this, two TaqMan 
qPCR assays were used to determine FCR and CRR pathogen population levels within fields. Because of their recent development, qPCR results were compared with the traditional methods of pathogen isolation and identification to examine their relative performance in this pathosystem. The resulting spatial distributions of FCR and CRR were assessed for their relationships to environmental variables as well as common production practices through a multifactorial analysis.

\section{Materials and Methods}

Counties surveyed and sampled. During summer 2008 and 2009, a survey was conducted involving 40 and 51 commercial wheat fields, respectively, from 10 counties throughout the northcentral and central regions of Montana (Fig. 1). The counties sampled were Blaine, Choteau, Fergus, Glacier, Hill, Judith Basin, Liberty, Phillips, Teton, and Toole. For each county, between two and nine fields were sampled each year. Sampled fields were randomly chosen with the help of the county extension agents of the respective counties. Fields selected were over 25 ha and were separated by a minimum of $2 \mathrm{~km}$. For each field, plant samples were collected within 14 days of harvest (either before or after). Samples were collected during 11 to 16 August 2008 and 10 to $25 \mathrm{Au}-$ gust 2009. For each field, samples were collected at 20 sites along a 600-m diagonal transect, with each site being approximately 30 $\mathrm{m}$ apart. Transect direction was variable and always started at least $30 \mathrm{~m}$ from the margin of the field, and was representative. At each sampling site, three randomly selected tillers were collected for a total of 60 tillers per field. The selected tillers were taken to the laboratory, where they were cleaned, dried, and stored at $4^{\circ} \mathrm{C}$ until they could be processed using qPCR or media-based isolation.

Coordinated with the field sampling, growers were surveyed about their cropping systems. Survey questions detailed wheat type (spring versus winter), cropping intensity, crop rotation, glyphosate usage, fungicide seed treatments, and nitrogen fertilizer applications. This information was used to categorize the crops and fields according to crop production factors and to determine association of these factors with pathogen populations as measured by $\mathrm{qPCR}$ quantification of targeted DNA sequences.

Quantification of crown and root rot infection on field samples. For DNA extractions and qPCR quantification, 3-mm stem sections were cut from the first internode of 30 randomly selected tillers per field sample. Subsequent handling, processing, and DNA extraction of the stem sections followed previously established protocols (30). Real-time quantification of pathogen populations was conducted using probes dual-labeled with the 6-carboxyfluorescein fluorescent reporter dye and the 6-carboxyltetramethylrhodamine fluorescence quencher. The probe and primers used for quantification of Fusarium populations were previously described by Strausbaugh et al. (59) and modified by Hogg et al. (29). This assay was specific for the three main species in the FCR complex: $F$. culmorum, $F$. pseudograminearum, and $F$. graminearum. The probe and primers used for $B$. sorokiniana were designed using the partial DNA sequence of the glyceraldeyde-3-phosphate dehydrogenase-like $(g p d)$ gene from $B$. sorokiniana isolate ND93-1 (GenBank accession EF513209.1). The probe sequence was 5'TCCATGGAGCGAGACTGGGCGC-3', which is located between the 377 and $398 \mathrm{bp}$ of the gpd sequence. The forward and reverse primer sequences were $5^{\prime}$-GAAGGACCCCGCCAACA- $3^{\prime}$ and $5^{\prime}$ CCGCTACACTCGACGACGTAGT-3', respectively. All amplifications were carried out in a Rotor-Gene Q (Qiagen Inc., Valencia, CA) using a two-step protocol with the following thermocycling parameters: $2 \mathrm{~min}$ at $55^{\circ} \mathrm{C}, 10 \mathrm{~min}$ at $94^{\circ} \mathrm{C}$, and 40 cycles of $15 \mathrm{~s}$ at $94^{\circ} \mathrm{C}$ and $60 \mathrm{~s}$ at $60^{\circ} \mathrm{C}$. qPCR reactions $(25 \mu \mathrm{l})$ consisted of $12.5 \mu \mathrm{l}$ of Universal TaqMan Master Mix (PE Applied Biosystems, Foster City, CA), $2.5 \mu \mathrm{l}$ of $2 \mu \mathrm{M}$ TaqMan probe, $2.25 \mu \mathrm{l}$ of a 1:1 mixture of $20 \mu \mathrm{M}$ forward and reverse primer solutions (Integrated DNA Technologies, Inc., Coralville, IA), $2.75 \mu \mathrm{l}$ of molecular-grade water, and $5 \mu \mathrm{l}$ of DNA sample. Each real-time run included five 10-fold-dilution standards, ranging from 660 copies to 6.6 million copies. Standard curves produced by plotting the log of the DNA

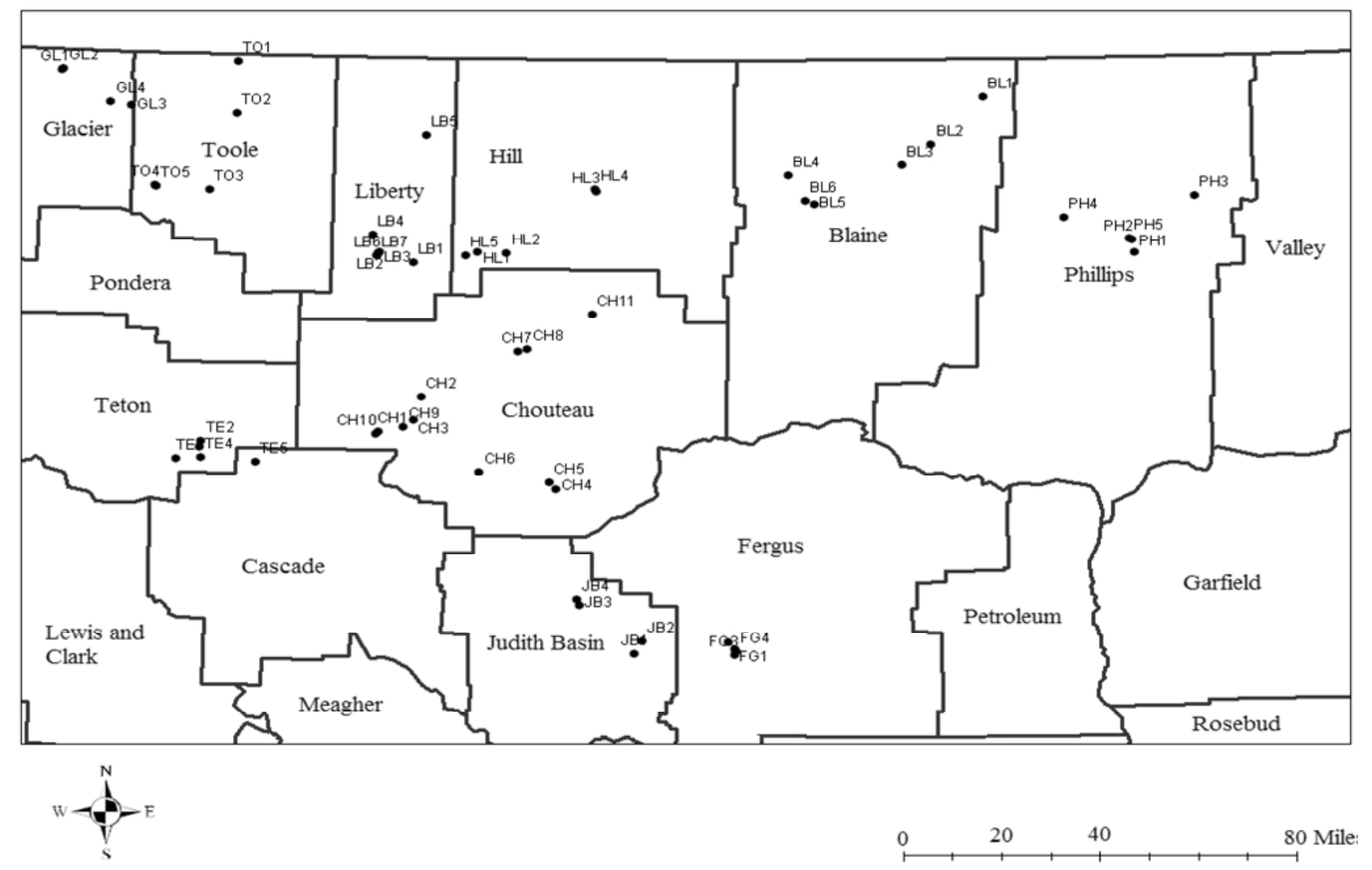

Fig. 1. Spatial distribution of survey sites in 10 Montana counties sampled during 2008 and 2009 . Sampled fields are coded according to county where the field was located and the number assigned to each field in the county prior to taking the samples. 
standards concentrations versus the cycle threshold $\left(\mathrm{C}_{\mathrm{t}}\right)$ values showed strong relationships ( $R$ values always exceeded 0.99$)$. Both the DNA standards and no-template control samples were run in triplicate for each real-time run. DNA field samples were run three times and the average of the three runs was considered the level of crown and root rot infection present in the field. To avoid artifacts from primer dimmers, a cut-off value of 36 cycles was established for $\mathrm{C}_{\mathrm{t}}$, the cycle number at which the fluorescence generated within the reaction crossed the threshold for being significantly different from the baseline or background signal.

For Fusarium spp., the DNA standard used for absolute quantification during qPCR was a cloned fragment of the tri5 gene from $F$. culmorum, isolate 2223 (29). For B. sorokiniana, a 507-bp fragment of the gpd gene from isolate 2243 (collected in Chester, MT) was cloned using Invitrogen's (Carlsbad, CA) TOPO TA cloning kit as per the manufacturer's instructions. A gpd gene fragment was amplified using forward primer 5'-TAAAGCTGACCCTGT GTCTCAGCA-3' and reverse primer 5'-AGAGAACCTCAA TGTCGGGCTTGT-3'. Colony selections were confirmed by PCR amplification. Because the B. sorokiniana assay was new, its specificity and sensitivity was tested across the following plant pathogens: F. culmorum, F pseudograminearum, F. graminearum, $F$. sambucinum Fuckel (teleomorph $G$. pulicaris), F. avenaceum, $F$. acuminatum Ellis \& Everh. (teleomorph G. acuminata Wollenw.), F. solani (Mart.) Sacc., F. oxysporum Schltdl., F. verticillioides (Sacc.) Nirenberg (syn. F. moniliforme J. Sheld.), F. equiseti, F. poae (Peck) Wollenw., F. sporotrichioides Sherb. (syns. F. tricinctumdand F. sporotrichiella var. sporotrichioides (Sherb.) Bilâ̌), Verticillium dahliae Kleb., Thielaviopsis basicola (Berk. \& Broome) Ferraris (syn. Chalara elegans Nag Raj \& W.B. Kendr.), Cephalosporium gramineum Y. Nisik. \& Ikata (syn. Hymenula cerealis Ellis \& Everh.), Gaeumannomyces graminis var. tritici J. Walker, Pythium ultimum Trow, Phialophora spp., Sclerotinia sclerotiorum (Lib.) de Bary, Aphanomyces cochlioides Drechsler, Penicillium claviforme Bainier, Oculimacula yallundae (Wallwork \& Spoonee) Crous \& W. Gams (syn. Tapesia yallundae), Rhizoctonia solani Kühn, and B. maydis (Y. Nisik. \& C. Miyake) Shoemaker (teleomorph $=$ Cochliobolus heterostrophus (Drechsler) Drechsler; syn. Helminthosporium maydis Y. Nisik. \& C. Miyake). For each species, $10 \mathrm{ng}$ of DNA was tested via qPCR to check for nonspecific reactions and experiments were repeated once in their entirety. The only fungi amplified by this assay were B. maydis and B. sorokiniana. Both species had similar amplification curves. To monitor inhibition in the qPCR reactions, all undiluted DNA samples were spiked with $335 \mathrm{pg}$ of plasmid containing the $\beta$-actin gene (mjba-1) from Meloidogyne javanica (40). No inhibition was observed in any of the samples based on qPCR results.

Isolation and identification of pathogens. To determine the root and crown rot pathogens involved in the infection of the stems and to corroborate qPCR results, additional 3-mm segments were excised from the first internodes of the 30 wheat tillers used for qPCR quantification. These new segments were used to assess presence of Fusarium spp., B. sorokiniana, and other pathogen species in these tissues through culturing on a general and selective media. One-half of the segments were plated onto $50 \%$ potato dextrose agar (PDA) amended with antibiotics (100 $\mu \mathrm{g}$ of streptomycin sulfate, $100 \mu \mathrm{g}$ of tetracycline sulfate, and $50 \mu \mathrm{g}$ of neomycin sulfate). The other half of the stem segments were plated onto a media selective for Bipolaris spp. (57), because the slow growing B. sorokiniana was easily overgrown by Fusarium mycelia on PDA. Prior to plating, stem segments were disinfected with $0.54 \%$ sodium hypochlorite solution for $30 \mathrm{~s}$, rinsed with sterile distilled water, and dried on a sterile paper towel. Five disinfected segments were placed on each media plate. Plates were incubated at $23 \pm 1{ }^{\circ} \mathrm{C}$ and monitored daily for fungal growth. Resulting fungal colonies were hyphal tipped and placed onto PDA to develop monoxenic cultures. All resulting isolates were identified to genus using morphologic and culture characteristics. All Fusarium cultures were transferred to carnation leaf amended (CLA) media for identification to species using traditional species identification characteristics $(38,62)$.
Isolates of $B$. sorokiniana and other fungi were identified under a microscope according the characteristics of their conidia and mycelia (6). The number and identity of fungi were recorded for each sample. These data were used to correlate relationships between isolation frequencies and the population sizes as determined by the qPCR assays. In consideration that F. culmorum, F. pseudograminearum, and $F$. graminearum are all detected by the qPCR Fusarium assay, these pathogens were considered as members of the FCR complex when used to compare isolation and qPCR assay results.

Relationship between pathogen populations and grain yield. To study the relationships between disease pathogen populations and grain yield, four selected fields in 2008 and five selected fields in 2009 were intensively sampled. For 2008, intensive sampling was done in two dryland winter wheat fields and one spring wheat field in Choteau County and one irrigated spring wheat field in Phillips County. In 2009, intensive sampling occurred on two dryland winter wheat fields, one each in Phillip and Chouteau counties; two dryland spring wheat fields, one each in Glacier and Blaine counties; and a repeated sampling of the irrigated spring wheat field from Phillips County that had been sampled in 2008. Intensive sampling involved collecting 20 crown and grain samples from 20 arbitrarily selected sites along a $600-\mathrm{m}$ transect within each field. For each sampling site, heads were collected from $1 \mathrm{~m}^{2}$ to determine yield and 60 tillers collected from the corresponding area being analyzed for FCR and CRR pathogen populations by the qPCR method described above. For this article, pathogen populations are equated to disease infestation. The grain was harvested from collected heads using a Vogel thresher (Bill's Welding, Pullman, WA), cleaned, and weighed.

Environmental and spatial characterization of field infection. All fields were geo-referenced through Google Earth software (http://www.google.com/earth/index.html). In cases where no precise global positioning system (GPS) location for the field could be determined, coordinates were matched to the nearby geographical place names recognizable in the spatial database. In addition to locations, elevation for each GPS field position was registered. For each survey location, data for average growing degree-days between May and August, average annual temperatures and precipitation, growth period temperature and precipitation (April to August), general soil types, and soil water-holding capacity were extracted with ArcViewGIS (version 9.0; ESRI, Redland, CA) from the geographical information system (GIS) database MAP Atlas 6.0 (11). All environmental data were analyzed on either an individual pathogen species basis or as a group of species according to their environmental association using a Spearman's coefficient of rank correlation.

Data analysis. DNA copy numbers obtained through qPCR for each disease of interest were $\log (x+1)$ transformed to reduce variance instability within the data sets. In addition, zero values were trimmed from data sets when comparisons between results of qPCR and isolation methods were made using correlation coefficients and linear regressions. Across years, Levene's test of homogeneity of variance found variances homogenous and, therefore, the data from both years were combined. Pearson's and Spearman's correlation coefficients and linear regressions were performed to examine various relationships between disease and pathogen populations as determined by qPCR or conventional methods and other measured parameters using the PROC COR and PROC REG procedures of SAS software (version 9.2; SAS Institute, Inc., Cary, NC). A standard $\chi^{2}$ test was used to compare frequencies of infested fields by county obtained through isolation methods and qPCR assay for each disease. Multiregression analyses were conducted to assess additive effects or interaction between populations of FCR pathogen species and B. sorokiniana as quantified by qPCR and grain yield for the extensively sampled fields, considering each individual field, and for a generalized model where the field factor was a fixed effect.

Geospatial statistics were used to determine significant spatial patterns for the different populations of both pathogen groups and fungal species determined through $\mathrm{qPCR}$ and plating. All fields 
(with or without FCR and CRR pathogens) were included in the analysis, and tests for spatial autocorrelation were undertaken using Moran's I values and transforming them to $z$ scores. This statistic provides an evaluation of whether the observed distribution pattern for an exhibited fungal species is clustered, dispersed, or random. All latitudinal and longitudinal coordinates for the field locations were corrected to a decimal degree and tests for each fungal species were implemented within the spatial statistics component from the PROC VARIOGRAM of SAS.

Relationships between the extracted environmental variables from the GIS database and population of both pathogen groups obtained by qPCR or percentage of infection for each pathogen of interest were analyzed using PROC COR. Spearman's coefficient of rank correlation was used to avoid variance differences and distribution effect of analyzed variables. In addition, Kruskal-Wallis rank sum tests and nonparametric multiple comparisons for the differences in ranks with a Wilcoxon rank-sum tests and Benjamini-Hochberg correction method were conducted to determine differences in level of plant infection among the general soil type classifications for Montana by using the packages "Rcmdr" and "PairwiseCI" of the R-Software (www.r-project.org).

Associations between crop production factors and values obtained from the qPCR quantification were analyzed using a bivariate distance vector in a permutation multivariable analysis of variance (PerMANOVA) through the adonis function from the package "vegan" of the R-software. This function permits the analysis of univariate or multivariate data using any distance measure and linear model. The calculated statistic (pseudo-F) is calculated, like a traditional $F$ statistic, as the sum of the squared distances among groups divided by the sum of the squared distances within groups relative to the overall sum of the pairwise distances $(1,36)$. This statistical method uses Euclidean distance permutations to generate the MANOVA by assuming the same distribution for all the groups or variables analyzed. Nonparametric Wilcoxon-Mann-Whitney or Kruskal-Wallis tests were considered to determine significant differences between two or more groups in the crop factor variables by using the Package "Rcmdr" of R-Software.

\section{Results}

Fungal populations as determined by traditional isolation methods. The field incidence rates for FCR and CRR pathogens were 51 and $92 \%$, respectively, as determined by conventional isolation methods. F. culmorum was detected in $36 \%$ of the fields and F. pseudograminearum was detected in $31 \%$ of the fields, with both pathogens being present in $16 \%$ of the fields. Overall, these two pathogens were isolated from $20 \%$ of the tillers examined. Populations as determined by rates of isolation showed that F. cul- morum was the dominant FCR pathogen in Glacier, Toole, and Blaine counties while $F$. pseudograminearum was dominant in Phillips and Teton counties (Table 1). The third FCR complex species, $F$. graminearum, was not detected. Across the 2 years, the three species ( $F$. culmorum, $F$. pseudograminearum, and $F$. graminearum) were absent from 45 of the sampled fields, which includes all of the fields in Judith Basin and Fergus counties (Table 1). The CRR pathogen, B. sorokiniana, was detected in all counties sampled (Table 1) and was absent from just seven fields, all located in either Chouteau or Liberty county. Using selective media, $B$. sorokiniana was isolated from $15 \%$ of tillers examined (Table 1). The highest populations, as indicated by isolation frequencies, were in Fergus, Judith Basin, and Blaine counties. Numerous other known wheat pathogens were isolated. Those detected in a significant percentage of the fields included $F$. acuminatum (32\%), $F$. avenaceum (16\%), F. equiseti (55\%), Microdochium nivale (21\%), F. oxysporum (19\%), F. sporotrichioides (19\%), F. redolens Wollenw. (27\%), F. dimerum Penz. (24\%), F. solani (10\%), G. graminis var. tritici (4\%), and an unknown Phaeosphaeria sp. (49\%). The unreported Phaeosphaeria sp. was initially thought to be an Oculimacula sp., given the predominance of isolations coming from winter wheat $(62.5 \%$ winter wheat versus $35.3 \%$ spring wheat). However, later amplification, isolation, and sequencing of the internal transcribed spacer region for several of these isolates followed by BLAST searches found that the fungus had closest sequence similarity (98\%) to Phaeosphaeria pontiformis (GenBank accession FN386303.1), a noted grass epiphyte (64). Isolates of the take-all pathogen was found in only three irrigated fields located in Teton County and one irrigated field located in Phillips County. Other genera of fungi isolated included Alternaria, Torula, Curvularia, Trichoderma, Rhizoctonia, Penicillium, Nigrospora, Epicoccum, Trichotecium, and several unidentified, nonsporulating cultures. All of these were rare and isolated at frequencies of less than $3 \%$ of the total samples (data not shown).

Fungal populations as determined by qPCR methods. FCR and CRR pathogens were present in 57 and $93 \%$ of the fields, respectively, as determined by real-time qPCR. These values were not significantly different from those determined by traditional culturing methods (FCR, $\chi^{2}=1.964, P=0.992$; CRR, $\chi^{2}=0.041$, $P=1.00)$. Average DNA copy number for Fusarium spp. and $B$. sorokiniana were 148,497 and 18,669, respectively (Table 2). As determined by qPCR, members of the FCR complex were not detected in fields from Judith Basin and Fergus counties. In contrast, DNA copy numbers for the FCR complex were at their highest in fields sampled in Toole and Glacier counties (mean $=340,577$ and 250,580 , respectively). In all, $12 \%$ of the fields had copy numbers in excess of 400,000 for the FCR assay (range $=415,770$ to

Table 1. Incidence on a percentage of infected tiller basis for pathogens causing Fusarium crown rot (FCR) and common root rot (CRR) as determined by plate culturing of 3-mm wheat internode segments in 10 counties surveyed during 2008 and 2009 in Montana

\begin{tabular}{|c|c|c|c|c|c|c|}
\hline \multirow[b]{2}{*}{ County } & \multirow[b]{2}{*}{ Sampled fields } & \multirow[b]{2}{*}{ Plated tillers $^{\mathrm{z}}$} & \multicolumn{4}{|c|}{ Incidence $(\%)^{\mathrm{y}}$} \\
\hline & & & $F c$ & Fpg & Ftotal & $B s$ \\
\hline Judith Basin & 8 & 120 & 0 & 0 & 0 & 19 \\
\hline Fergus & 8 & 120 & 0 & 0 & 0 & 28 \\
\hline Phillips & 8 & 120 & 10 & 17 & 27 & 16 \\
\hline Blaine & 9 & 135 & 14 & 10 & 24 & 19 \\
\hline Chouteau & 16 & 240 & 11 & 7 & 18 & 7 \\
\hline Liberty & 11 & 165 & 4 & 10 & 13 & 18 \\
\hline Hill & 9 & 135 & 1 & 4 & 5 & 17 \\
\hline Toole & 9 & 135 & 23 & 5 & 28 & 12 \\
\hline Glacier & 7 & 105 & 63 & 6 & 69 & 12 \\
\hline Teton & 6 & 90 & 12 & 21 & 33 & 13 \\
\hline Total tillers & 91 & 1,365 & 174 & 103 & 277 & 210 \\
\hline Incidence (\%) & $\ldots$ & $\ldots$ & 13 & 8 & 20 & 15 \\
\hline
\end{tabular}

y Pathogens species causing FCR were Fusarium culmorum $(F c), F$. pseudograminearum $(F p g)$, and Bipolaris sorokiniana (Bs) for CRR. Sum of total tillers infected by $F$. culmorum and $F$ pseudograminearum (Ftotal) is also shown.

${ }^{\mathrm{z}}$ Total number of tillers plated in potato dextrose agar and reisolated in carnation leaf-agar (CLA) for FCR pathogens or a selective B. sorokiniana media for CRR (57). Tillers have been used previously in a real-time quantitative polymerase chain reaction analysis of both diseases, and 15 internode segments were sampled per field for each media. 
1,925,597, mean $=770,719)$. In comparison, populations of $B$. sorokiniana were relatively homogeneous as determined by qPCR, except in Glacier and Teton counties, where populations were particularly low (means $=6,397$ and 5,476, respectively; Table 2). In all, $15 \%$ of the fields had particularly high levels of B. sorokiniana, with DNA copies numbers $>40,000$ copies $(44,790$ to 90,243 copies, mean $=59,900$; Table 2). In 2008, DNA copies numbers for the FCR complex and for $B$. sorokiniana were negatively correlated with each other at both the field and county level (Spearman's coefficients: $r=$ $-0.319, P=0.044$ and $r=-0.798, P=0.005$, respectively). For 2009, these relationships were not present (Spearman's coefficients: $r=$ -0.194 . $P=0.171$ and $r=-0.243, P=0.498$, respectively).

Results from a comparison of $\mathrm{qPCR}$ and traditional isolation methods were positively correlated with each other for the two pathogen systems (Pearson's coefficients: FCR, $r=0.714, P=$ $<0.001$; CRR, $r=0.525, P=<0.001)$. A linear regression model explained $51 \%$ of the variation between both methods for FCR pathogen species $(P<0.001$; Fig. $2 \mathrm{~A})$, whereas only a $28 \%$ of the variation was explained for B. sorokiniana $(P<0.001$; Fig. $2 \mathrm{~B})$.

Intensively sampled fields. For the nine intensively sampled fields, relationships between yield and the populations of both the FCR complex and B. sorokiniana as indicated by log DNA copy numbers were analyzed both years (Table 3). Among these, the FCR complex populations had significant negative correlations with yield in two dryland winter wheat and one spring wheat fields. For the 20 sampled sites in the dryland winter wheat fields in Chouteau (CH1) and Phillips counties (PH5), FCR complex populations ranged from 0 to $3,454,704$ and 690 to 1,255,929 DNA copy numbers of the tri5 gene, respectively. When yields were regressed against population, an FCR population of 400,000 DNA copies was associated with a yield loss of $25 \%$ in the $\mathrm{CH} 1 \mathrm{Chou}-$ teau field and $35 \%$ in the PH5 Phillips County field. The irrigated spring wheat field sampled both years in Phillips County (PH3) had a marked increase in FCR complex populations in the second year, which was negatively correlated with yield in that year (Table 3 ). In this case, the population of the FCR complex ranged from 9,059 to $2,417,753$ DNA copies and a population of 400,000 DNA copies indicated a $21 \%$ decrease in yield. One additional spring wheat field from Blaine County in 2009 (BL5) showed a positive correlation between Fusarium populations and yield (Pearson's coefficient: $r=0.524, P=0.0177)$. However, the removal of two extreme outliers from this analysis resulted in an insignificant relationship (Pearson's coefficient: $r=0.326, P=0.1862$ ). For $B$. sorokiniana, log DNA copy numbers were negatively correlated with yield in the irrigated spring wheat field sampled in Phillips County

Table 2. Mean DNA copy number populations of Fusarium crown rot (FCR) and common root rot (CRR) determined by using real-time quantitative polymerase chain reactions for fields located in 10 counties surveyed during 2008 and 2009 in Montana

\begin{tabular}{lccc}
\hline & & \multicolumn{2}{c}{ DNA copy numbers } \\
\cline { 3 - 4 } County & Sampled fields & ${\text { Fusarium } \text { spp. }^{\mathbf{y}}}^{\text {B. sorokiniana }^{\mathbf{z}}}$ \\
\hline Judith Basin & 8 & 0 & 20,322 \\
Fergus & 8 & 0 & 22,050 \\
Phillips & 8 & 188,876 & 24,424 \\
Blaine & 9 & 222,831 & 32,377 \\
Chouteau & 16 & 161,594 & 12,607 \\
Liberty & 11 & 100,903 & 24,358 \\
Hill & 9 & 62,598 & 24,424 \\
Toole & 9 & 340,577 & 13,421 \\
Glacier & 7 & 250,580 & 7,234 \\
Teton & 6 & 157,010 & 5,476 \\
Overall mean & $\ldots$ & 148,497 & 18,669 \\
Total fields & 91 & $\ldots$ & $\ldots$ \\
\hline
\end{tabular}

y FCR TaqMan probe was able to quantify Fusarium culmorum, F. pseudograminearum, and $F$. graminearum populations in wheat internodes based in quantification of the DNA copy number of the tri5 gene.

${ }^{\mathrm{z}}$ CRR TaqMan probe was able to quantify Bipolaris sorokiniana populations in wheat internodes based in quantification of the DNA copy number of the gpd gene. in both years of the study, and one dryland spring wheat crop in Glacier County in 2009 (Table 3). For the 20 sampled sites in the irrigated field in Phillips County (PH3) in 2008 and 2009, populations of B. sorokiniana ranged from 26,048 to 196,289 and 16,965 to 196,004 DNA copy numbers of the gpd gene for each year, respectively. When yields were regressed, a population of 40,000 DNA copy numbers was associated with a decrease in yield of 3 and $13 \%$ for the irrigated PH3 Phillips County field in 2008 and 2009 , respectively. A $31 \%$ decrease in yield was found for the dryland field from Glacier County (GL1) when the population of $B$. sorokiniana ranged between 2,243 to 87,898 DNA copy numbers. A multiple regression analysis did not detect any effect on grain yield for the interaction between populations of FCR and CRR when field was considered as a fixed effect $\left(R^{2}=0.796, P=0.619\right)$ although, in two fields ( $\mathrm{CH} 1$ and PH3 during 2008) which were analyzed individually by using multiple regression, the interactions were significant $(P=0.084$ and 0.062 , respectively, and $P=0.084$ and 0.062 , respectively).

Spatial distribution and environmental factors. The high variability observed in population levels as detected by qPCR and traditional isolation methods motivated efforts to analyze spatial patterns for both diseases using a Moran's I $z$-score statistic. This analysis showed significant spatial autocorrelations being detected for populations of both the FCR complex and B. sorokiniana as
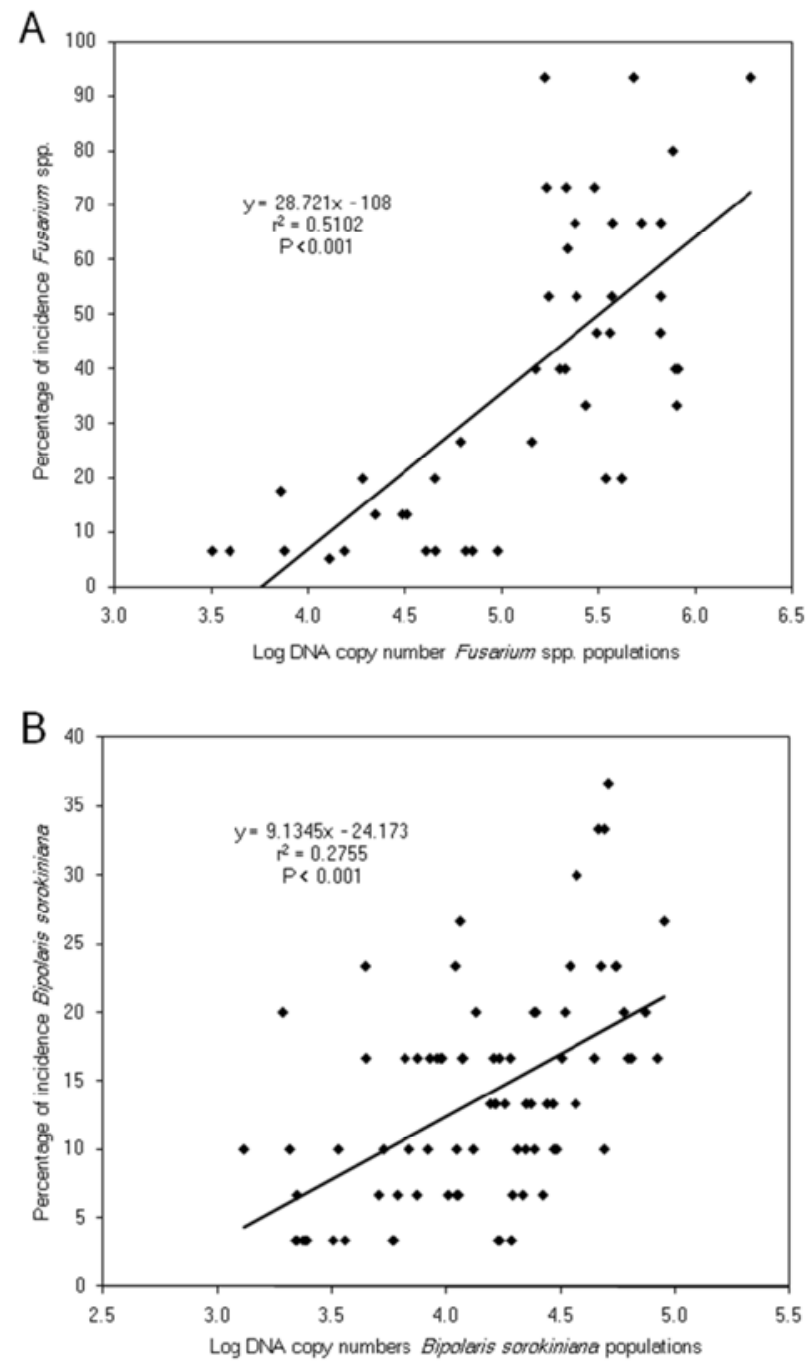

Fig. 2. Relationships between percentage of infected tillers as determined by traditional culturing methods and pathogen populations as determined by quantitative real-time PCR assays for A, Fusarium crown rot and B, common root rot pathogens. Zero values were trimmed from data sets to avoid variance restrictions. The resulting analyses were conducted across 46 and 83 fields for the Fusarium crown rot complex and Bipolaris sorokiniana, respectively. 
represented by DNA copy numbers (FCR complex, $z=9.76, P<$ 0.001; CRR populations, $z=3.51, P<0.001$ ). Field incidence levels as determined by isolation methods were autocorrelated for F. culmorum $(z=11.74, P<0.001), B$. sorokiniana $(z=4.11, P<$ 0.001 ), and the combined $F$. culmorum and $F$. pseudograminearum incidences $(z=8.40, P<0.001)$. These results implied that the spatial distributions for each pathogen were in highly clustered, nonrandom patterns. Incidence for $F$. pseudograminearum was not significantly autocorrelated $(z=1.20, P=0.232)$ and this implied that populations of this pathogen were dispersed randomly among the fields in the surveyed area. Because of the spatial autocorrelation results, environmental variables, including growing degreedays, elevation, and average and maximum temperatures and precipitation, were examined for associations with defined areas of disease concentration. From these analyses, it was found that FCR complex populations as measured by qPCR were negatively correlated with annual temperatures (Spearman's rank coefficient: $r=$ $-0.271, P=0.009$ ) whereas $B$. sorokiniana populations as measured by qPCR were positively correlated with elevation $(r=0.228, P=$ $0.030)$, growing degree-days $(r=0.230, P=0.029)$, and average and maximum temperatures observed in June $(r=0.254, P=0.015$ and $r=0.229, P=0.029$, respectively), and July ( $r=0.260, P=$ 0.012 and $r=0.207, P=0.048$, respectively) and with maximum temperature in August ( $r=0.231, P=0.027)$. Populations of $F$. culmorum as determined by traditional isolation methods were negatively correlated with annual temperature (Spearman's rank coefficient: $r=-0.414, P<0.001)$ and average and maximum temperatures observed during June $(r=-0.269, P=0.009$ and $r=$ $-0.258 P=0.001$, respectively), July $(r=-0.2834, P=0.007$ and $r$ $=-0.267 P=0.010$, respectively $)$, and August $(r=-0.279, P=$ 0.007 and $r=-0.347, P<0.001$, respectively). Field incidences of $F$. pseudograminearum were positively correlated with elevation (Spearman's rank coefficient: $r=0.212, P=0.037$ ), growing degree-days $(r=0.210, P=0.046)$, soil water-holding capacity $(r=$ $0.221, P=0.035)$, average temperatures in August $(r=0.236, P=$ 0.024), and maximum temperatures observed during summer months (June, $r=0.174, P=0.098$; July, $r=0.183, P=0.082$; and August, $r=0.176, P=0.094)$. Field incidence level for $B$. sorokiniana as determined by traditional media isolation did not correlate with any environmental parameter (data not shown).

Table 3. Pearson's correlation coefficients between grain yield $\left(\mathrm{g} / \mathrm{m}^{2}\right)$ and $\log$ DNA quantities (copy number) of Fusarium crown rot (FCR) pathogens and common root rot (CRR) pathogen in 20 sampled sites $\left(1 \mathrm{~m}^{2}\right)$ for nine fields extensively sampled in the north-central and central region of Montana during the crop seasons of 2008 and 2009

\begin{tabular}{|c|c|c|c|c|c|c|}
\hline \multirow[b]{2}{*}{ Field $^{v}$} & \multirow[b]{2}{*}{ Wheat type } & \multirow[b]{2}{*}{ Cropping system } & \multirow[b]{2}{*}{ Year } & \multirow[b]{2}{*}{ Dominant pathogens ${ }^{\mathrm{w}}$} & \multicolumn{2}{|c|}{ Pearson's coefficient of correlation $(P \text { value })^{u}$} \\
\hline & & & & & Fusarium spp. ${ }^{\mathrm{x}}$ & B. sorokiniana ${ }^{y}$ \\
\hline $\mathrm{CH} 1$ & Winter & Dryland & 2008 & Fpg/Bs & $-0.488(0.029)$ & $-0.236(0.315)$ \\
\hline $\mathrm{CH} 2$ & Winter & Dryland & 2008 & Fpg/Bs & $-0.210(0.374)$ & $-0.033(0.889)$ \\
\hline $\mathrm{CH} 6$ & Spring & Dryland & 2008 & $F c-F p g / B s$ & $0.194(0.410)$ & $-0.249(0.288)$ \\
\hline PH3 & Spring & Irrigated & 2008 & Fpg/Bs & $0.232(0.324)$ & $-0.693(<0.001)$ \\
\hline $\mathrm{CH} 9$ & Winter & Dryland & 2009 & $F C-F p g / B s$ & $-0.195(0.408)$ & $0.218(0.354)$ \\
\hline PH5 & Winter & Dryland & 2009 & $F p g / B s$ & $-0.462(0.040)$ & $0.174(0.462)$ \\
\hline BL5 & Spring & Dryland & 2009 & Fpg/Bs & $0.326(0.186)^{\mathrm{z}}$ & $0.009(0.969)$ \\
\hline GL1 & Spring & Dryland & 2009 & Fpg/Bs & $-0.076(0.749)$ & $-0.422(0.064)$ \\
\hline PH3 & Spring & Irrigated & 2009 & Fpg/Bs & $-0.524(0.012)$ & $-0.637(0.003)$ \\
\hline
\end{tabular}

"Correlations among variables were considered significant at $P<0.05$

${ }^{\mathrm{v}}$ Fields were coded by putting the initial letter for each county where the field was located and the number assigned to each field in the county previously to taking the samples in a regional survey. The irrigated spring wheat crop field coded PH3 was sampled in both 2008 and 2009.

${ }^{w}$ Dominant pathogens species were Fusarium culmorum $(F c)$ and $F$. pseudograminearum $(F p g)$ for FCR and Bipolaris sorokiniana (Bs) for CRR. Dominant species in each field were determined by plate culturing method from data collected during a 2-year survey conducted in the northern and central regions of Montana.

${ }^{x}$ FCR TaqMan probe was able to quantify F. culmorum, F. pseudograminearum, and F. graminearum populations in wheat internodes based in quantification of the DNA copy number of the tri5 gene.

${ }^{y}$ CRR TaqMan probe was able to quantify B. sorokiniana populations in wheat internodes based in quantification of the DNA copy number of the gpd gene.

${ }^{\mathrm{z}}$ Value reported is the result of two outliers being removed from the data set. With the additional data points, $r=0.524$ and $P=0.018$.

Table 4. Mean DNA copy number as determined by quantitative polymerase chain reaction and percentage of incidence as determined by conventional isolation methods for Fusarium crown rot (FCR) and common root rot (CRR) and their associated pathogens observed in surveyed fields for seven different soil types in Montana (2008 to 2009) ${ }^{\mathrm{u}}$

\begin{tabular}{|c|c|c|c|c|c|c|}
\hline \multirow[b]{2}{*}{ Soil typew } & \multirow[b]{2}{*}{ Sampled fields } & \multicolumn{2}{|c|}{ DNA copy numbers } & \multicolumn{3}{|c|}{ Percentage of incidence ${ }^{v}$} \\
\hline & & FCR $^{\mathbf{x}}$ & $\mathbf{C R R}^{\mathrm{y}}$ & $F c$ & Fpg & $B s$ \\
\hline Gb5 & 12 & $0.0 \mathrm{~b}$ & 23,884 & $0.0 \mathrm{c}$ & $0.0 \mathrm{c}$ & 16.4 \\
\hline$S g 2$ & 23 & $123,224 \mathrm{a}$ & 18,063 & $15.4 \mathrm{~b}$ & $9.3 \mathrm{bc}$ & 9.6 \\
\hline Gb4 & 4 & $298,737 \mathrm{a}$ & 8,624 & $58.3 \mathrm{a}$ & $0.0 \mathrm{c}$ & 15.9 \\
\hline$S g 1$ & 16 & 139,162 a & 26,738 & $10.8 \mathrm{~b}$ & $0.4 \mathrm{c}$ & 15.6 \\
\hline Apl & 8 & $150,902 \mathrm{a}$ & 25,713 & $3.3 \mathrm{bc}$ & $17.5 \mathrm{ab}$ & 17.5 \\
\hline Og2 & 8 & $152,990 \mathrm{a}$ & 22,323 & $8.3 \mathrm{bc}$ & $5.8 \mathrm{bc}$ & 9.6 \\
\hline $\mathrm{Pb} 2$ & 4 & $173,053 \mathrm{a}$ & 5,833 & $6.7 \mathrm{bc}$ & $28.3 \mathrm{a}$ & 5.8 \\
\hline Total fields & 75 & $\ldots$ & $\ldots$ & $\ldots$ & $\ldots$ & $\ldots$ \\
\hline$P$ value ${ }^{\mathrm{z}}$ & $\ldots$ & 0.005 & 0.089 & 0.005 & 0.029 & 0.055 \\
\hline
\end{tabular}

"Means followed by the same letter in each column were not significantly different according to a nonparametric multiple comparisons for the difference in ranks with a Wilcoxon test and Benjamini-Hochberg adjustment $(\alpha=0.05)$. Mean separations were done on copy numbers $\log (x+1)$ transformed for the DNA copy number of the tri5 and gpd genes for FCR and CRR, respectively.

${ }^{v}$ Pathogens species causing FCR were Fusarium culmorum $(F c)$ and F. pseudograminearum (Fpg) and causing CRR was Bipolaris sorokiniana (Bs).

${ }^{\text {w }}$ General soils of Montana: $G b 5=$ Argiborolls-Calciborolls; $S g 2=$ Argiborolls-Paleargids-Natrargids; $G b 4=$ Argiborolls; $S g 1=$ Argiborolls-Haploborolls; $A p 1=$ Torrifluvents-Salorthids; $O g 2=($ Mollisols $)$ Argiborolls-Haploborolls; $P b 2=$ Calciborolls-Calciorthids.

${ }^{x}$ FCR TaqMan probe was able to quantify F. culmorum, F. pseudograminearum, and $F$. graminearum populations in wheat internodes based on DNA copy number of the tri5 gene.

y CRR TaqMan probe was able to quantify B. sorokiniana populations in wheat internodes based on DNA copy number of the gpd gene.

${ }^{\mathrm{z}} P$ values obtained after to conduct Kruskal-Wallis rank sum tests for each variable. 
In addition to these environmental variables, general soil types were analyzed as pathogen population factors using the KruskalWallis sum rank test and nonparametric means comparison (Table 4). Soil types were significantly different for log DNA copy numbers for the FCR complex as quantified by qPCR $\left(\chi^{2}=18.42, P=\right.$ $0.005)$. Wheat samples grown in silty soil type $G b 5$ from Fergus County and near Stanford in Judith Basin County had FCR infections different from samples grown in the other soil types examined. Log DNA copy numbers for $B$. sorokiniana were not significantly different among the different soil types $\left(\chi^{2}=10.97, P=\right.$ $0.089)$. F . culmorum and $F$. pseudograminearum populations as quantified by plating method were significantly different $\left(\chi^{2}=\right.$ $18.35, P=0.005$ and $\chi^{2}=14.07, P=0.029$, respectively). Clayey and shallow clay of the $G b 4$ soil type from the northern portion of Glacier County had a high incidence of $F$. culmorum (58.3\%), while the clayey and shallow clay soils of $P b 2$ type in the irrigated fields in Teton County and the Apl soil type from Phillips County were more associated with $F$. pseudograminearum $(17.5 \%)$. The lowest incidence for $B$. sorokiniana was observed in the $P b 2$ soils from Teton County (5.8\%); however, no differences were observed among soil types $\left(\chi^{2}=12.33, P=0.055\right.$; Table 4$)$.

Cropping factors. Cropping factors, including tillage, crop rotations, glyphosate herbicide treatments, fungicide seed treatment, nitrogen fertilizer rates, and wheat types, were analyzed by PerMANOVA for their impacts on log DNA copy numbers for the pathogens as determined by qPCR. The only significant effect was for wheat type, where DNA copy numbers for the FCR complex populations were significantly different (pseudo- $F=1.413, P<$ 0.001 ) in spring wheat (mean $=285,662$ copies) than in winter wheat $($ mean $=63,929$ copies). No statistical differences were detected for $B$. sorokiniana populations.

\section{Discussion}

For this survey, B. sorokiniana was found to be the most widespread crown pathogen within the Golden Triangle of Montana. This result is comparable with surveys reported in Canada $(5,21,27,61)$ and the United States $(28,57,69)$ but is significantly different than distributions reported in the Pacific Northwest, where CRR was of only secondary concern (55). The high incidence of $B$. sorokiniana is not explained by the use of $B$. sorokiniana selective media for this study, which only increased the overall isolation rates for $B$. sorokiniana relative to the nonselective media by $2.7 \%$. Although B. sorokiniana was more widespread than the FCR complex, the population sizes were often an order of magnitude smaller as quantified by qPCR. Whether the results of the two qPCR assays are comparable in this manner or whether protocols bias the result toward the FCR complex is unknown. Certainly, the hallmark infection court for the CRR pathogen is the subcrown internode and, unlike the FCR complex $(17,34)$, it is not noted for aggressively colonizing the lower tiller. For that reason, the first internodes used for this study are probably a biased sample when comparisons are made between these pathogen species. With that said, severe CRR infections, which are likely to significantly affect yield, generally extend beyond the crown into the first internode tissues and, therefore, these tissues should act as a good point for measuring CRR severity and the impacts of CRR on wheat production in Montana.

Among the complex of species associated with the FCR complex in Montana, F. culmorum dominated. Its populations were highly structured, which suggests that they may have reached equilibrium with their environmental and ecological constraints across the region. This pattern was similarly expressed for B. sorokiniana where, despite an almost ubiquitous distribution, its populations were found structured based on environmental parameters, such as elevation, which has been associated with $B$. sorokiniana distribution in another survey (63). Environmental associations with $F$. culmorum showed that the fungus preferred the cooler areas of the Golden Triangle, particularly in the northern regions and along the Rocky Mountain front. This conforms to previous observations of this pathogen being a cool-weather pathogen $(12,13,41)$. Similarly, the observation that $F$. pseudograminearum prefers warmer conditions (13) was also confirmed by this survey, where the proportion of infection by $F$. pseudograminearum was positively correlated with maximum temperature during the summer months. In contrast to $F$. culmorum, populations of $F$. pseudograminearum showed a nonclustered, random distribution, suggesting that this pathogen is still colonizing the region and has yet to become bound by environmental or ecological constraints. This adaptation of $F$. pseudograminearum to warm conditions in Montana could be used in the future to assess changes associated with global warming.

It is interesting to note that FCR was not found in 45 of 91 fields surveyed. This shows the high variability of FCR populations throughout the survey area. For most fields, this absence may or may not indicate a lack of endemicity for the pathogen complex However, the universal absence of the FCR complex from 16 fields sampled in Judith Basin and Fergus counties may very well indicate that, for whatever reason, these pathogens are not endemic to these counties. Within the Golden Triangle, these counties are rather unique within the surveyed region for another reason, and that is that they sit on top of the Judith Bench, with soils generally characterized as silt-loams (Argiborolls-Calciborolls). Also, Fergus and Judith Basin counties are part of a different agroecoregion than that present in the North Plains of Montana, with higher precipitation and lower temperatures and evapotraspiration rates compared with the dominant agroecological region present in the other surveyed counties (39). The impact of agroecological zones on the distribution and prevalence of crown and root rot pathogens has been clearly observed in another survey done by Tunali et al. (63), who showed that incidence of Fusarium spp. are varied among 11 agroecological zones in Turkey. In addition, growers in the Fergus and Judith Basin counties area typically annually crop their fields and use longer crop rotations than growers in most of the remaining areas surveyed (data not presented). Although this study could find no link between disease and rotation or cropping intensity, soil types and some environmental variables were significantly associated with FCR pathogens and may potentially explain the absence of FCR in Judith Basin and Fergus counties. Curiously, F. graminearum, the third member of this complex, was never isolated from any of the samples collected across the region. In addition to being a devastating floral pathogen, $F$. graminearum has been shown to be an aggressive crown rot pathogen capable of competing efficiently with the other two members in the FCR complex (15). In recent years, this pathogen has caused localized head blight outbreaks within the southern and eastern portions of Montana (10) and it will be interesting to follow its populations to see if they can become established in areas not conducive to head blight.

Among the assorted other fungi isolated from field samples, a fungus initially suspected of being an Oculimacula sp. but later found to be an unknown Phaeosphaeria sp. was dominant. The isolation rates for this fungus exceeded the combined incidence rate for F. culmorum and F. pseudograminearum. Although it is not addressed by this study, the prevalence of this putative Phaeosphaeria sp. suggests that it deserves further evaluation for its importance in Montana and possibly elsewhere.

Assorted other fusaria (besides the FCR complex) were isolated from tiller material at rates lower than $B$ sorokiniana and the unknown Phaeosphaeria sp. Among them, F. equiseti, $F$. acuminatum, $F$. redolens, and $F$. dimerum were detected in over $20 \%$ of the fields sampled. Of these $F$. equiseti, F. acuminatum, and $F$. dimerum are considered to be less pathogenic (56) and their effects on wheat crops are not well characterized. The fourth fusaria, $F$. redolens, was considered conspecific with $F$. oxysporum (38) but recently has been considered a separate clade from the $F$. oxysporum complex $(3,7)$. F redolens is known to affect asparagus (3), onion (51), pea, and bean (8) but $F$. redolens has not been described as infecting wheat before now. High distribution of this fungus may be associated with the recent incorporation of dry pea in crop rotations for this area but additional studies will be required to identify whether this association occurs. Assorted other fusaria were found at lesser 
frequencies and are likely to play only minor roles in the crown and root rot complexes.

DNA copies for the FCR pathogens were particularly high in $12 \%$ of the fields sampled (in excess of 400,000 copies). These levels of infestation expressed in DNA copy numbers of the tri5 gene have been correlated with yield losses and high disease severity scores for FCR in the first internode (29). For intensively sampled fields, these levels of the pathogen were associated with losses of 25 and $35 \%$ for the dryland fields and $21 \%$ for the second year of wheat recrop in an irrigated field. Although attributing losses to disease survey results is always tricky, it would be safe to assume that these heavily infested fields were severely affected by FCR and that the growers are experiencing significant FCR-related losses. Like the FCR complex, populations of B. sorokiniana, as expressed in DNA copy numbers, were in excess of 40,000 copies in $15 \%$ of the fields. Losses associated with these populations were less than those attributed to FCR, with losses of 3 and $13 \%$ for both years in the irrigated field, respectively, and $31 \%$ for a dryland field. From these numbers, it is hard to assess which disease is causing the largest losses in the area. Although losses are greater for individual fields affected by higher population of FCR pathogens, $B$. sorokiniana is more widely dispersed and is causing more generalized losses for the region. It also should be noted that populations of these two pathogen groups were negatively correlated with each other in the first year of the study and not in the second. Negative correlations between these diseases have been reported by others at survey level (21), which would suggest, in the one case, that, if these pathogens are separating due to niche differentiation, then the diseases could be addressed individually but, if they are antagonistic, that control of one may simply result in replacement by the other and only limited yield gains would be recognized by control of the individual diseases. Considering that antagonism between fusaria pathogens and $B$. sorokiniana has been described under controlled conditions $(23,33,47,60)$, population replacement between pathogens seem likely to occur. Antagonistic responses or interaction between fusaria and B. sorokiniana pathogens were not clearly defined in this survey at the field level. However, population dynamics between both pathogens has been studied in an experimental setting under field conditions by using the qPCR assays by Moya-Elizondo et al. (37).

The DNA copies for the FCR complex were higher in spring wheat than winter wheat. These results confirm early work conducted in the Pacific Northwest, where FCR was more severe in spring wheat than in winter wheat (54). Other crop factors such as growth type, tillage, crop rotation, seed treatments, nitrogen rates, water availability, and use of glyphosate did not show any relationship to either FCR or CRR. These results contrast with others where pathogen abundance and disease severity for both FCR and CRR were influenced by crop rotation, cropping history, tillage system, and use of glyphosate (18-20,22,24). Fernandez's work $(18-20,22,24)$ was conducted in a more homogenous environment than occurred in this study, where topology and environment varied greatly across counties. In addition, the sampling in Fernandez's studies was more robust as well. Because of the variability, results for this study are considered less conclusive with respect to cropping factors and not contradictory to the work of Fernandez.

To our knowledge, this is the first survey to assess crown and root rot of wheat using real-time qPCR. Incidences and populations as determined the qPCR assays were not significantly different from those obtained using traditional isolation methods commonly used in the past $(4,12,14,17-19,21,25,26,45,46,53,55,57,58,63$, $66,67)$, suggesting that qPCR is an adequate tool to diagnose FCR and CRR in future surveys. In some respects, the qPCR assays appear to be superior to previous methods, particularly in providing a greater range of assessment for pathogen populations and corresponding disease infestation at the field level. This appears to have led to a greater sensitivity for pathogen detection because both pathogens were detected in more fields with qPCR than with traditional isolation methods. In addition, these measures were not subject to interspecies interference that can dominate culturing methods and which necessitated our switching B. sorokiniana assessment to a selective media. Additionally, differences in cost between the two methodologies are almost similar. qPCR was around \$14 for DNA extraction and triplicate assays for FCR and CRR pathogens. Conventional plating in two growth media (PDA-CLA and selective CRR media) cost about $\$ 8.2$ per field sampled. However, when time of labor to process 20 field samples was considered, the qPCR analysis and the conventional method required 21 and $38 \mathrm{~h}$, respectively. When the value of labor (@ $\$ 10.00 / \mathrm{h}$ ) for 20 field samples was considered, the traditional method cost $\$ 170$ dollars more.

For this survey, the qPCR assays were nonspecific, detecting pathogens from the FCR complex and the genus Bipolaris. These assays are useful when generalized results are wanted for FCR or where only one species from the said genus is present and pathogenic to the crop in question, as with $B$. sorokiniana and CRR of wheat in Montana. When these conditions are not met, other tools such as traditional isolations or specific PCR assays are needed. Already, specific PCR assays are available for $F$. culmorum, $F$. pseudograminearum, $F$. graminearum $(2,49,50), F$. avenaceum (49), F. poae (42), F. acuminatum, (68), and F. oxysporum (16). Others are likely to be developed in the near future.

In previous work, DNA copy numbers for the FCR complex were found to be at their highest at harvest and, if crowns were left in situ, these copy numbers dropped off steadily until the spring of the next year (30). For this reason, samples taken for this study were taken within 2 weeks or less of harvest to minimize the effects of copy number instability. This self-imposed restriction was probably the largest drawback to the use of qPCR for surveys because it limited sampling to the busiest time of the year. How timing affects outcomes for competing methods is unknown and beyond the scope of this study. Certainly, it is likely that the isolation frequency for the FCR complex and B. sorokiniana would be maximized by limiting sampling to within a few days of harvest. Similarly, crown discoloration or bleaching probably vary relative to days before or after harvest.

This is the first report on the qPCR assay for B. sorokiniana developed for this study. Primers and probe from the glyceraldeyde3-phosphate dehydrogenase-like gene sequence used in this assay were tested on 23 species likely to occur within Montana's survey and did not amplify any of these species. The assay's results corresponded well to results obtained using traditional isolation methods, which showed that assay was useful for these circumstances. Another closely related species, B. maydis, which is not common to this area, did amplify with the assay at levels similar to those seen with B. sorokiniana DNA. This was not unexpected because sequence information on other species within the genus is not available, making species-specific design challenging. At this time, B. maydis is not prevalent within Montana. If corn production spreads into the region, this assay may not be as useful for examining the CRR pathogen in the field.

This survey is the first systematic assessment of FCR and CRR pathogen distribution and prevalence conducted in the area called the Golden Triangle of wheat production in the state of Montana. From this survey, it was shown that CRR pathogen is the most widespread within the Golden Triangle production area of central Montana, while the pathogens that cause FCR are more variable throughout the region. In particular, FCR pathogens were not found in the silty loam fields of Judith Basin and Fergus counties. When high infestations by pathogen populations of both diseases were observed, they caused significant losses. For B. sorokiniana, this could occur in $15 \%$ of the fields while, for FCR pathogens, this occurred in $12 \%$ of the fields. This is the first time that qPCR was used to survey wheat fields for FCR and CRR pathogen groups, and results from these analyses were comparable with traditional isolation methods but had key advantages and disadvantages that may need to be addressed. Analysis of environmental parameters showed that $F$. culmorum incidence is favored by cooler summers while $F$. pseudograminearum is favored by warmer summers, as previously reported $(12,13,41)$. Finally, populations of the 
FCR complex and B. sorokiniana negatively correlated with each other in 2008. Although these correlations were not observed in 2009 , reports from others suggest that this may be a real phenomenon that needs to be explored because of the practical control implications that it may represent $(21,23,33,37,47,60)$. The possible antagonism or niche exclusion dynamic between these two diseases and associated pathogens may have practical implications. Development of fungicide seed treatments, cultivar resistance, or changes in tillage practices to reduce FCR or CRR may not result in the yield gains that one might expect, because yield gains may be partially offset by increasing losses due to the other disease.

\section{Acknowledgments}

This research was supported in part by funds from the Montana Wheat and Barley Committee and Montana Agricultural Experiment Station. We thank the county extension agents of the Montana State University Extension Service in the area surveyed for their support and assistance; the growers who collaborated with this project; and D. Cooksey for sharing with us the Map Atlas 6.0 software used in this study.

\section{Literature Cited}

1. Anderson, M. J. 2001. A new method for non-parametric multivariate analysis of variance. Aust. Ecol. 26:32-46.

2. Aoki, T., and O'Donnell, K. 1999. Morphological and molecular characterization of Fusarium pseudograminearum sp. nov., formerly recognized as the group I population of $F$. graminearum. Mycologia 91:597-609.

3. Baayen, R. P., van den Boogert, P. H .J .F., Bonants, P. J. M., Poll, J .T .K., Blok, W. J., and Waalwijk, C. 2000. Fusarium redolens f.sp asparagi, causal agent of asparagus root rot, crown rot and spear rot. Eur. J. Plant Pathol. 106:907-912.

4. Backhouse, D., Abubakar, A. A., Burgess, L. W., Dennis, J. I., Hollaway, G. J., Wildermuth, G. B., and Henry, F. J. 2004. Survey of Fusarium species associated with crown rot of wheat and barley in eastern Australia. Australas. Plant Pathol. 33:255-261.

5. Bailey, K. L., Duczek, L. J., Kutcher, H. R., and Buckley, H. L. 1995. Saskatchewan cereal root disease survey, 1994. Can. Plant Dis. Surv. 75:122123.

6. Barnett, H. L., and Hunter, B. B. 1998. Illustrated Genera of Imperfect Fungi. American Phytopathological Society, St. Paul, MN.

7. Bogale, M., Wingfield, B. D., Wingfield, M. J., and Steenkamp, E. T. 2007. Species-specific primers for Fusarium redolens and a PCR-RFLP technique to distinguish among three clades of Fusarium oxysporum. FEMS Microbiol. Lett. 271:27-32.

8. Booth, C. 1971. The Genus Fusarium. Commonwealth Mycological Institute, Kew, UK.

9. Burgess, L. W., Backhouse, D., Summerell, B. A., and Swan, L. J. 2001. Crown rot of wheat. Pages 271-295 in: Fusarium-Paul E. Nelson Memorial Symposium. B. A. Summerell, J. F. Leslie, D. Backhouse, W. L. Bryden, and L. W. Burgess, eds. American Phytopathological Society, St. Paul, MN.

10. Burrows, M., Grey, W., and Dyer, A. T. 2008. Small grain treatment guide. MontGuide: MT200806AG..

11. Caprio, J. M., Cooksey, D. I., Erlien, C. M., Jacobsen, J. S., Nielsen, G. A., and Roche, R. R.. 2006. MAPS Atlas Version 6.0 Software, A Land and Climate Information System. Montana State University, Bozeman.

12. Cook, R. J. 1968. Fusarium root and foot rot of cereals in the Pacific Northwest. Phytopathology 58:127-131.

13. Cook, R. J. 1981. Fusarium diseases of wheat and other small grains in North America. Pages 39-52 in: Fusarium: Diseases, Biology, and Taxonomy. P. E. Nelson, T. A. Toussoun, and R. J. Cook, eds. Pennsylvania State University Press, University Park.

14. Diehl, J. A. 1979. Common root rot of wheat in Brazil. Plant Dis. Rep. 63:1020-1022.

15. Dyer, A. T., Johnston, R. H., Hogg, A. C., and Johnston, J. A. 2009. Comparison of pathogenicity of the Fusarium crown rot complex (F. culmorum, $F$. pseudograminearum and $F$. graminearum) on hard red spring and durum wheat. Eur. J. Plant Pathol. 125:387-395.

16. Edel, V., Steinberg, C., Gautheron, N., and Alabouvette, C. 2000. Ribosomal DNA-targeted oligonucleotide probe and PCR assay specific for Fusarium oxysporum. Mycol. Res. 104:518-526.

17. Fedel-Moen, R., and Harris, J. R. 1987. Stratified distribution of Fusarium and Bipolaris on wheat and barley with dryland root rot in South Australia. Plant Pathol. 36:447-454.

18. Fernandez, M. R., Basnyat, P., and Zentner, R. P. 2007. Response of common root rot in wheat to crop management in eastern Saskatchewan. Can. J. Plant Sci. 87:953-963.

19. Fernandez, M. R., Holzgang, G., and Turkington, T. K. 2009. Common root rot of barley in Saskatchewan and north-central Alberta. Can. J. Plant Pathol. 31:96-102.

20. Fernandez, M. R., Huber, D., Basnyat, P., and Zentner, R. P. 2008. Impact of agronomic practices on populations of Fusarium and other fungi in ce- real and noncereal crop residues on the Canadian Prairies. Soil Tillage Res. 100:60-71.

21. Fernandez, M. R., and Jefferson, P. G. 2004. Fungal populations in roots and crowns of common and durum wheat in Saskatchewan. Can. J. Plant Pathol. 26:325-334

22. Fernandez, M. R., Selles, F., Gehl, D., DePauw, R. M., and Zentner, R. P. 2005. Crop production factors associated with Fusarium head blight in spring wheat in Eastern Saskatchewan. Crop Sci. 45:1908-1916.

23. Fernandez, J. A., Wofford, D. S., and Horton, J. L. 1985. Augmentation of wheat common root rot by Fusarium acuminatum. Mycopathologia 90:177179.

24. Fernandez, M. R., Zentner, R. P., DePauw, R. M., Gehl, D., and Stevenson, F. C. 2007. Impacts of crop production factors on common root rot of barley in Eastern Saskatchewan. Crop Sci. 47:1585-1595.

25. Gonzalez, M. S., and Trevathan, L. E. 2000. Identity and pathogenicity of fungi associated with root and crown rot of soft red winter wheat grown on the upper coastal plain land resource area of Mississippi. J. Phytopathol. 148:77-85.

26. Hall, R., and Sutton, J. C. 1998. Relation of weather, crop, and soil variables to the prevalence, incidence, and severity of basal infections of winter wheat in Ontario. Can. J. Plant Pathol. 20:69-80.

27. Harding, H. 1973. Fungi associated with subcrown internodes of wheat (Triticum aestivum). Can. J. Bot. 51:2514-2516.

28. Hill, J. P., Fernandez, J. A., and McShane, M. S. 1983. Fungi associated with common root rot of winter wheat in Colorado and Wyoming. Plant Dis. 67:795-797.

29. Hogg, A. C., Johnston, R. H., and Dyer, A. T. 2007. Applying real-time quantitative PCR to Fusarium crown rot of wheat. Plant Dis. 91:1021-1028.

30. Hogg, A. C., Johnston, R. H., Johnston, J. A., Klouser, L., Kephart, K. D. and Dyer, A. T. 2010. Monitoring Fusarium crown rot populations in spring wheat residues using quantitative real-time polymerase chain reaction. Phytopathology 100:49-57.

31. Hollingsworth, C. R., Atkinson, L. M., Samac, D. A., Larsen, J. E., Motteberg, C. D., Abrahamson, M. D., Glogoza, P., and MacRae, I. V. 2008. Region and field level distributions of aster yellows phytoplasma in small grain crops. Plant Dis. 92:623-630.

32. Krupa, S., Bowersox, V., Claybrooke, R., Barnes, C. W., Szabo, L., Harlin, K., and Kurle, J. 2006. Introduction of Asian soybean rust urediniospores into the Midwestern United States-a case study. Plant Dis. 90:1254-1259.

33. Ledingham, R. J. 1942. Observation on antagonism in inoculation tests of wheat with Helminthosporium sativus P.K. \& B., and Fusarium culmorum (W.G. SM.) Sacc. Sci. Agric. 22:688-697.

34. Ledingham, R. J., Atkinson, T. G., Horricks, J. S., Mills, J. T., Piening, L. J., and Tinline, R. D. 1973. Wheat losses due to common root rot in the prairie provinces of Canada 1969-71. Can. Plant Dis. Surv. 53:113-122.

35. Luo, Y., Ma, Z., Reyes, H. C., Morgan, D. P., and Michailides, T. J. 2007. Using real-time PCR to survey frequency of azoxystrobin-resistant allele G143A in Alternaria populations from almond and pistachio orchards in California. Pestic. Biochem. Physiol. 88:328-336.

36. McArdle, B. H., and Anderson, M. J. 2001. Fitting multivariate models to community data: a comment on distance based redundancy analysis. Ecology 82:290-297.

37. Moya-Elizondo, E. A., Jacobsen, B. J., Hogg, A. C., and Dyer, A. T. 2011 Population dynamics between Fusarium pseudograminearum and Bipolaris sorokiniana in wheat stems using real-time qPCR. Plant Dis. 95:1089-1098.

38. Nelson, P. E., Toussoun, T. A., and Marasas, W. F. 1983. Fusarium Species: An Illustrated Manual for Identification. The Pennsylvania State University Press, University Park.

39. Padbury, G., Waltman, S., Caprio, J., Coen, G., McGinn, S., Mortensen, D. Nielsen, G., and Sinclair, R. 2002. Agroecosystems and land resources of the Northern Great Plains. Agron. J. 94:251-261.

40. Painter, J. E., and Lambert, K. N. 2003. Meloidogyne javanica chorismate mutase transcript expression profile using real-time quantitative RT-PCR. J. Nematol. 35:82-87.

41. Papendick, R. I., and Cook, R. J. 1974. Plant water stress and development of Fusarium foot rot in wheat subjected to different cultural practices. Phytopathology 64:358-363.

42. Parry, D. W., and Nicholson, P. 1996. Development of a PCR assay to detect Fusarium poae in wheat. Plant Pathol. 45:383-391.

43. Paulitz, T. C. 2006. Low input no-till cereal production in the Pacific Northwest of the U.S.: the challenge of root disease. Eur. J. Plant Pathol. 115:271-281

44. Paulitz, T. C., Smiley, R. W., and Cook, R. J. 2002. Insight into the prevalence and management of soilborne cereal pathogens under direct seeding in the Pacific Northwest, U.S.A. Can. J. Plant Pathol. 24:416-428.

45. Pettitt, T., Xu, X., and Parry, D. 2003. Association of Fusarium species in the wheat stem rot complex. Eur. J. Plant Pathol. 109:769-774.

46. Saremi, H., Ammarellou, A., and Jafary, H. 2007. Incidence of crown rot disease of wheat caused by Fusarium pseudograminearum as a new soil born fungal species in north west Iran. Pak. J. Biol. Sci. 10:3606-3612.

47. Scardaci, S. C., and Webster, R. K. 1981. Antagonism between the cerea root rot pathogens Fusarium graminearum and Bipolaris sorokiniana. Plant Dis. 65:965-967.

48. Schaad, N. W., and Frederick, R. D. 2002. Real-time PCR and its applica- 
tion for rapid plant disease diagnostics. Can. J. Plant Pathol. 24:250-258.

49. Schilling A. G., Möller E. M., and Geiger, H. H. 1996. Polymerase chain reaction-based assays for species-specific detection of Fusarium culmorum, $F$. graminearum, and $F$. avenaceum. Phytopathology 86:515-522.

50. Scott, J., Akinsami, O., Mitter, V., Simpfendorfer, S., Dill-Macky, R., and Chakraborty., S. 2003. Prevalence of Fusarium crown rot pathogens of wheat in southern Queensland and northern New South Wales. http:// www.cropscience.org.au/icsc2004/poster/2/4/2/1274_socttj.htm?print=1

51. Shinmura, A. 2002. Studies on the ecology and control of Welsh onion root rot caused by Fusarium redolens. J. Gen. Plant Pathol. 68:265.

52. Smiley, R. W., Collins, H. P., and Rasmussen, P. E. 1996. Disease of wheat in long-term agronomic experiments at Pendleton, Oregon. Plant Dis. 80:813-820.

53. Smiley, R. W., Gourlie, J. A., Easley, S. A., and Patterson, L. M. 2005. Pathogenicity of fungi associated with the wheat crown rot complex in Oregon and Washington. Plant Dis. 89:949-957.

54. Smiley, R. W., Gourlie, J. A., Easley, S. A., Patterson, L.-M., and Whittaker, R. G. 2005. Crop damage estimates for crown rot of wheat and barley in the Pacific Northwest. Plant Dis. 89:595-604.

55. Smiley, R. W., and Patterson, L.-M. 1996. Pathogenic fungi associated with Fusarium foot rot of winter wheat in the semiarid Pacific Northwest. Plant Dis. 80:944-949.

56. Smiley, R. W., and Yan, H. 2009. Variability of Fusarium crown rot tolerances among cultivars of spring and winter wheat. Plant Dis. 93:954-961.

57. Specht, L. P., and Rush, C. M. 1988. Fungi associated with root and foot rot of winter wheat and populations of Cochliobolus sativus in the Texas Panhandle. Plant Dis. 72:959-963.

58. Strausbaugh, C. A., Bradley, C. A., Koehn, A. C., and Forster, R. L. 2004. Survey of root diseases of wheat and barley in southeastern Idaho. Can. J. Plant Pathol. 26:167-176.

59. Strausbaugh, C. A., Overturf, K., and Koehn, A. C. 2005. Pathogenicity and real-time PCR detection of Fusarium spp. in wheat and barley roots. Can. J. Plant Pathol. 27:430-438.
60. Tinline, R. D. 1977. Multiple infections of subcrown internodes of wheat (Triticum aestivum) by common root rot fungi. Can. J. Bot. 55:30-34.

61. Tinline, R. D. 1994. Etiology of prematurity blight of hard red spring wheat and durum wheat in Saskatchewan. Can. J. Plant Pathol. 16:87-92.

62. Toussoun, T. A., and Nelson, P. E. 1976. A Pictorial Guide to the Identification of Fusarium species. American Phytopathological Society, The Pennsylvania State University Press, University Park.

63. Tunali, B., Nicol, J. M., Hodson, D., Uçkun, Z., Büyük, O., Erdurmuş, D., Hekimhan, H., Aktaș, H., Akbudak, M. A., and Bağci, S. A. 2008. Root and crown rot fungi associated with spring, facultative, and winter wheat in Turkey. Plant Dis. 92:1299-1306.

64. Van Ryckegem, G., and Verbeken, A. 2005. Fungal ecology and succession on Phragmites australis in a brackish tidal marsh. II. Stems. Fungal Divers. 20:209-233.

65. Wen, A., Mallik, I., Alvarado, V. Y., Pasche, J. S., Wang, X., Li, W., Levy, L., Lin, H., Scholthof, H. B., Mirkov, T. E., Rush, C. M., and Gudmestad, N. C. 2009. Detection, distribution, and genetic variability of 'Candidatus Liberibacter' species associated with zebra complex disease of potato in North America. Plant Dis. 93:1102-1115.

66. Wildermuth, G. B. 1986. Geographic distribution of common root rot and Bipolaris sorokiniana in Queensland wheat soils. Aust. J. Exp. Agric. 26:601-606.

67. Wildermuth, G. B., Thomas, G. A., Radford, B. J., McNamara, R. B., and Kelly, A. 1997. Crown rot and common root rot in wheat grown under different tillage and stubble treatments in southern Queensland, Australia. Soil Tillage Res. 44:211-224.

68. Williams K. J., Dennis J. J., Smyl C., and Wallwork, H. 2002. The application of species-specific assays based on the polymerase chain reaction to analyse Fusarium crown rot of durum wheat. Australas. Plant Pathol. 31:119-127.

69. Windels, C. E., and Holen, C. 1989. Association of Bipolaris sorokiniana, Fusarium graminearum Group 2, and F. culmorum on spring wheat differing in severity of common root rot. Plant Dis. 73:953-956. 